\title{
Respon Pemberian Ethyl Methane Sulfonate Terhadap Kualitas Salak Pondoh
}

\author{
Nandariyah"1), Sukaya ${ }^{1)}$, Via Liesdiana ${ }^{2)}$
}

\begin{abstract}
This research was conducted in Tapansari snakefruit plantation, Pakem, Sleman, Yogyakarta. This study use Completely Randomized Design with one factor. Factor used is the EMS concentration (K) difference that consists of 5 levels concentration of $0 \%, 0.5 \%, 1 \%, 1.5 \%$, and $2 \%$. The treatment is given to the female flowers from the tip to the base as much as $5 \mathrm{ml}$ in each before pollination. The data were analyzed using descriptive analysis and analysis of variance by the $\mathrm{F}$ test level of $5 \%$ and continued by DMRT level of $5 \%$. The result showed that application of EMS in the female flowers before pollination can reduce the size of some snakefruit sample in $1 \%, 1.5 \%$, and $2 \%$ concentrations; however, it did not show significant effect on the seed size reduction. The application of EMS does not able to produce seedless snakefruits.
\end{abstract}

Keywords : female flowers, genetic diversity, seedless, EMS

\section{PENDAHULUAN}

Tanaman salak (Salacca zalacca) merupakan salah satu tanaman buah yang disukai masyarakat Indonesia karena rasanya manis, dan memiliki prospek yang cukup baik untuk dibudidayakan(Gari 2011). Program pemuliaan salak untuk mendapatkan varietas unggul dengan perakitan ragam genetik salak masih sangat terbatas dan menjadi salah satu masalah pemerintah dalam pengembangan tanaman buah. Penelitian ini menggunakan zat kimia mutagenik yaitu Ethyl methane sulfonat (EMS). Pemberian EMS dengan konsentrasi 1\% pada anthera dan waktu aplikasi 1 MSP dapat meningkatkan tebal daging buah salak (Nandariyah et al 2014), sehingga pada penelitian ini diharapkan dapat meningkatkan kualitas tanaman salak dengan pemberian EMS pada bunga betina sebelum penyerbukan untuk melihat ada atau tidaknya pengaruh EMS terhadap kualitas buah salak seperti penebalan daging buah dan penurunan ukuran biji.

Tujuan dari penelitian ini antara lain mendapatkan penurunan ukuran biji salak dan mendapatkan konsentrasi EMS yang tepat terhadap pembentukan buah salak tanpa biji. Sedangkan manfaat dari penelitian ini adalah untuk memberikan informasi mengenai konsentrasi larutan EMS yang dapat

\footnotetext{
1)Lecturer Staff of Study Program of Agrotechnology, Faculty of Agriculture, Sebelas Maret University (UNS) on Surakarta.

2) Undergraduate Student of Study Program of Agrotechnology, Faculty of Agriculture, Sebelas Maret University (UNS) on Surakarta.

Contact Author: vialiesdiana@gmail.com
}

meningkatkan keragaman genetik yang selanjutnya dapat digunakan dalam pemuliaan tanaman untuk mendapatkan perbaikan kualitas salak pondoh.

\section{BAHAN DAN METODE}

Pelaksanaan penelitian ini pada bulan Mei 2015 sampai bulan Januari 2016 di kebun salak Tapansari, Pakem, Sleman, Yogyakarta. Penelitian ini menggunakan Rancangan Acak Lengkap (RAL) dengan satu faktor perlakuan. Faktor yang digunakan yaitu perbedaan konsentrasi (K) EMS yang terdiri dari 5 taraf yaitu konsentrasi $0 \% ; 0,5 \% ; 1 \% ; 1,5 \% ; 2 \%$ dan diulang sebanyak 6 kali. Perlakuan diberikan pada bunga betina yang belum diserbuki sebanyak $5 \mathrm{ml}$ pada setiap perlakuan. Hasil pengamatan selanjutnya dianalisis dengan menggunakan analisis ragam berdasarkan uji $\mathrm{F}$ taraf $5 \%$. Apabila terdapat pengaruh beda nyata, analisis dilanjutkan melalui uji DMRT dengan taraf $5 \%$.

\section{HASIL DAN PEMBAHASAN Jumlah Buah per Tandan}

Berdasarkan analisis ragam jumlah buah per tandan diketahui bahwa pemberian EMS berpengaruh nyata terhadap jumlah buah per tandan. Jumlah buah pertandan tertinggi pada perlakuan EMS 1,5\% yaitu 31 buah per tandan yang berbeda nyata dengan perlakuan kontrol yang hanya 11 buah per tandan. Menurut Jabeen (2002) EMS dengan konsentrasi 0,1\% juga dapat meningkatkan jumlah total buah cabai. 


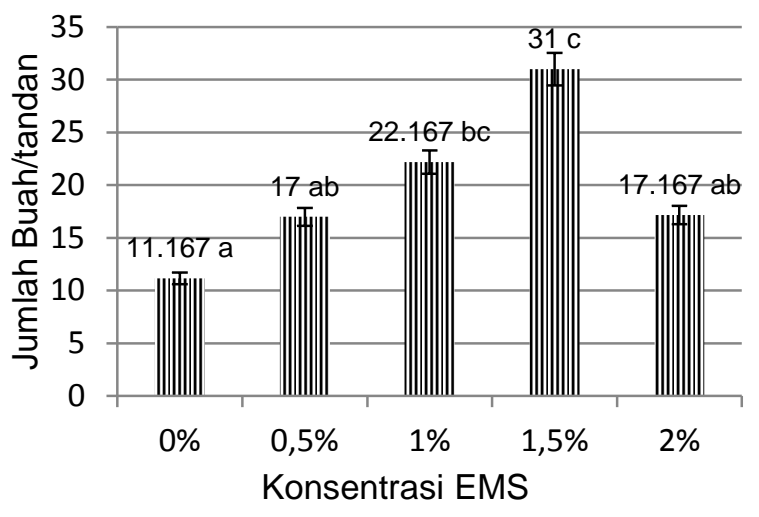

Keterangan :

Angka yang diikuti indeks huruf yang sama berarti tidak berbeda nyata berdasarkan uji DMRT taraf 5\%.

Gambar 1. Histogram Pemberian EMS terhadap Jumlah Buah per Tandan

\section{Berat Buah per Tandan}

Berdasarkan analisis ragam berat buah per tandan pemberian EMS pada bunga betina sebelum penyerbukan memberikan pengaruh nyata terhadap berat buah per tandan. Menurut Nurrochman, Trisnowati, dan Muhartini (2013) berat buah per tandan salak pondoh pada umumnya antara 700-1700 gram, sedangkan pada penelitian ini ditemukan satu tandan dengan berat 2000 gram pada pemberian EMS dengan konsentrasi $1,5 \%$. Hasil tersebut cukup signifikan dibandingkan dengan rata-rata hasil perlakuan kontrol yang hanya 600 gram per tandan.

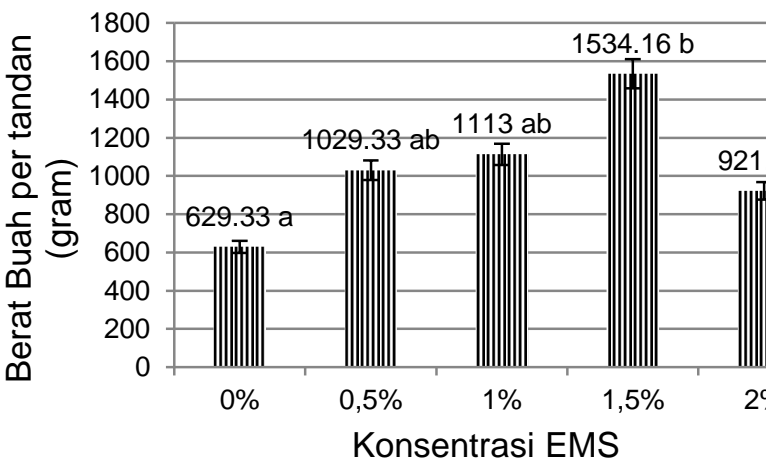

Keterangan :

Angka yang diikuti indeks huruf yang sama berarti tidak berbeda nyata berdasarkan uji DMRT taraf 5\%.

Gambar 2. Histogram Pemberian EMS terhadap Berat Buah per Tandan

Berat buah per tandan tertinggi yaitu pada pemberian EMS dengan konsentrasi 1,5\% sama dengan variable pengamatan jumlah buah per tandan. Hal tersebut menunjukkan bahwa pemberian EMS pada konsentrasi 1,5\%

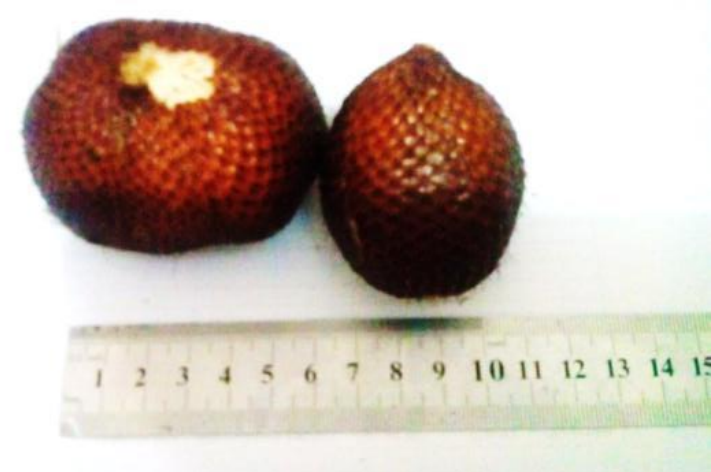

meningkatkan jumlah buah dan sekaligus berat per tandannya. Hal tersebut didukung pernyataan Gambar 3. Foto Buah pada pemberian EMS konsentrasi $1,5 \%$ yang memiliki berat satu buah paling besar.

Wiguna (2011) pada penelitiannya bahwa EMS konsentrasi $0,1 \%$ dapat meningkatkan berat seribu butir biji wortel. Pemberian konsentrasi EMS dengan konsentrasi $0,5 \%$ dan $1 \%$ menunjukkan hasil yang lebih tinggi dibandingkan dengan perlakuan kontrol dan mencapai berat tertinggi pada konsentrasi 1,5\%, sedangkan pada konsentrasi EMS 2\% mengalami penurunan berat buah per tandan. Menurut Manzila et al. (2010) pemberian EMS juga dapat menurunkan bobot buah cabai hingga 9,7\% pada perendaman EMS $0,5 \%$ selama 60 menit. Berat buah pertandan terendah pada penelitian ini yaitu pada perlakuan kontrol sebesar 629,33 gram per tandan.

\section{Berat Satu Buah}

Buah yang memiliki ukuran dan berat paling besar pada penelitian ini ditemukan pada konsentrasi 1,5\% dengan berat 61,14 gram (Gambar 3) namun hanya muncul beberapa sehingga masih lebih rendah dengan perlakuan pemberian EMS konsentrasi 0,5\%. Buah tersebut berbiji 3 sama dengan buah lain namun hanya ukuran dan berat satu buahnya yang lebih besar. Hal tersebut sejalan dengan pernyataan Qosim et al (2015) bahwa induksi mutasi dengan EMS dapat menyebabkan mutasi DNA yang berakibat pada perubahan morfologi, EMS juga menyebabkan mutasi titik sehingga perubahan yang terjadi acak.

Respon Pemberian Ethyl Methane Sulfonate Terhadap Kulaitas Salak Pondoh ........ 


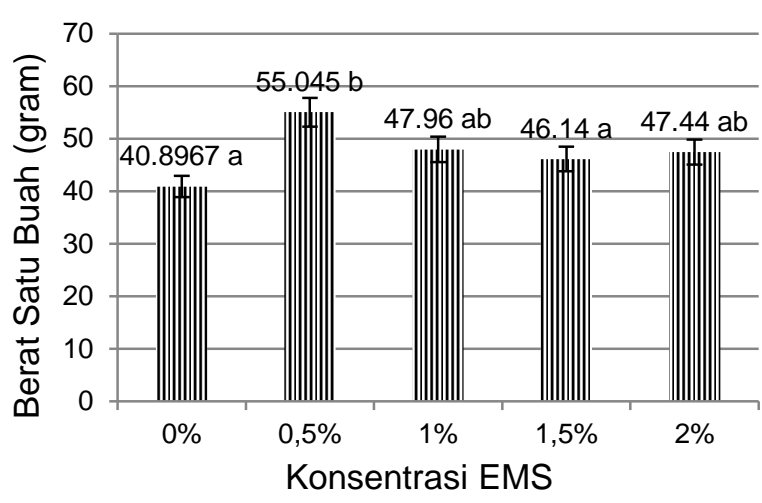

Keterangan :

Angka yang diikuti indeks huruf yang sama berarti tidak berbeda nyata berdasarkan uji DMRT taraf 5\%.

Gambar 4. Histogram Pemberian EMS terhadap Berat 1 Buah

Hasil analisis ragam berat satu buah menunjukkan bahwa pemberian EMS pada bunga betina salak berpengaruh nyata terhadap berat satu buah. Berat satu buah tertinggi didapatkan pada pemberian EMS dengan konsentrasi $0,5 \%$. Berat satu buah paling rendah yaitu pada perlakuan kontrol. Menurut saba (2002) pemberian EMS $0.5 \%$ yang diberikan pada benih cabai juga dapat meningkatkan hasil berat cabai.

\section{Tebal Daging Buah}

Berdasarkan analisis ragam tebal daging buah menunjukkan bahwa pemberian EMS pada bunga betina salak tidak berpengaruh nyata terhadap tebal daging buah salak. Tebal daging buah tertinggi yaitu pada pemberian EMS dengan konsentrasi $2 \%$ yaitu sebesar $2,94 \mathrm{~mm}$. Pemberian EMS dengan konsentrasi $0 \%$ atau perlakuan kontrol mendapatkan hasil tebal daging buah terendah yaitu sebesar $2,74 \mathrm{~mm}$. hal tersebut sejalan dengan pernyataan manzila et al. (2010) bahwa pemberian EMS pada konsentrasi $0,5 \%$ dapat meningkatkan diameter cabai hingga $10 \mathrm{~mm}$ dari kontrol yang hanya 2,90 $\mathrm{cm}$ menjadi $3,16 \mathrm{~cm}$.

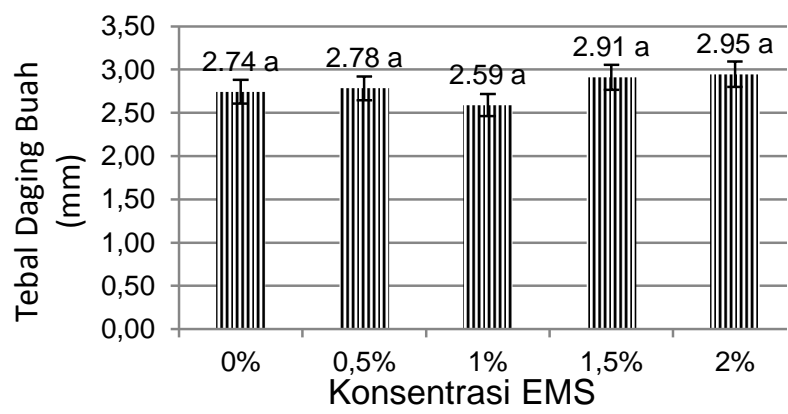

Keterangan :
Angka yang diikuti indeks huruf yang sama berarti tidak berbeda nyata berdasarkan uji DMRT taraf 5\%.

Gambar 5. Histogram Pemberian EMS terhadap Tebal Daging Buah

\section{Jumlah Biji per Buah}

Berdasarkan analisis ragam jumlah biji per buah hasil pemberian EMS terhadap bunga betina salak sebelum penyerbukan berpengaruh nyata terhadap jumlah biji per buah.Perlakuan kontrol menunjukkan hasil terendah dengan ratarata jumlah biji per buah yaitu 2. Jumlah biji per buah paling tinggi pada perlakuan EMS dengan konsentrasi $1,5 \%$ yaitu 2,8 yang berarti hampir seluruh buah berbiji 3 . Menurut Manzila et al. (2010) konsentrasi EMS yang dibutuhkan untuk menimbulkan mutasi pada setiap tanaman berbeda. Diduga dalam hal ini konsentrasi yang diberikan belum cukup untuk memberikan pengaruh terhadap jumlah biji per buah.

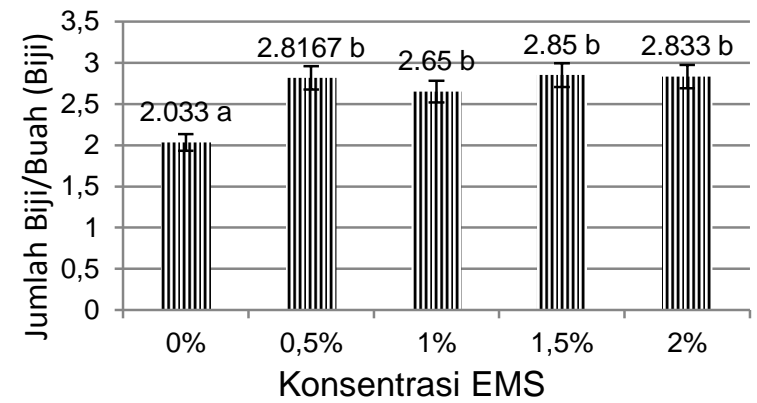

Keterangan :

Angka yang diikuti indeks huruf yang sama berarti tidak berbeda nyata berdasarkan uji DMRT taraf 5\%.

Gambar 6. Histogram Pemberian EMS terhadap Jumlah Biji per Buah

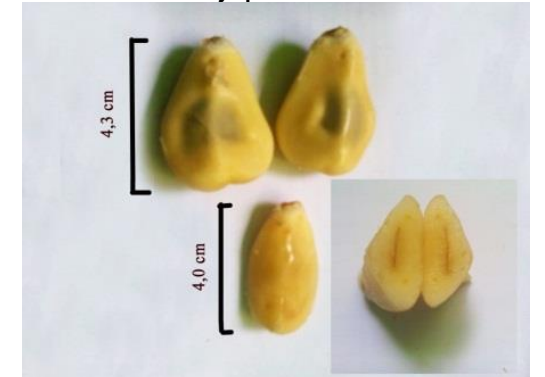

Gambar 7. Foto buah yang tidak memiliki biji dengan ukuran besar pada pemberian EMS konsentrasi 1,5\%

Pemberian EMS pada bunga betina sebelum penyerbukan selain meningkatkan jumlah biji per buah juga didapati 4 buah dengan buah tak berbiji yang pada umumnya berukuran kecil namun pada EMS konsentrasi 1,5\% didapatkan suing buah tak berbiji yang sebesar ukuran 2 siung lainnya. Menurut pratiwi (2013) perlakuan mutagen menghasilkan kerusakan fisiologis yang rendah dan menghasilkan pengaruh genetik yang menguntungkan yang 
dalam hal ini meningkatkan kualitas bua salak. Selain itu, mutasi dengan induksi harus berkelanjutan, mudah diterapkan, efisien, ramah lingkungan, dan fleksibel (Devi and Mullainathan 2012).

\section{Berat Biji per Buah}

Berdasarkan analisis ragam Berat Biji per Buah pemberian EMS pada bunga betina salak sebelum penyerbukan berpengaruh nyata terhadap berat biji per buah. Berat biji per buah tertinggi diperoleh dari pemberian EMS dengan konsentrasi $0,5 \%$ yaitu sebesar 11,75 gram. Perlakuan kontrol mendapatkan berat biji per buah terendah yaitu sebesar 8,14 gram.

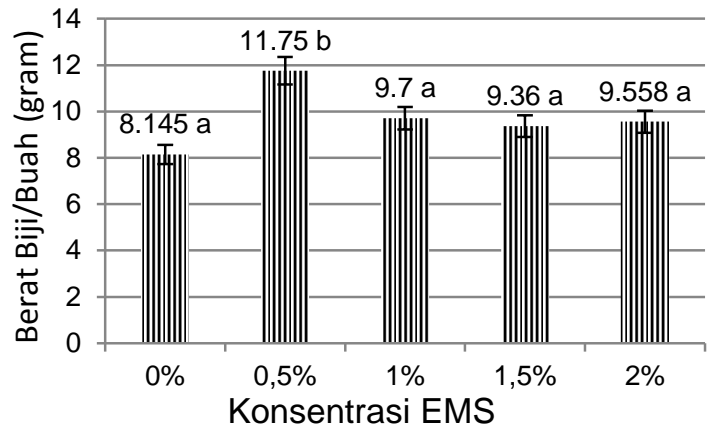

Keterangan :

Angka yang diikuti indeks huruf yang sama berarti tidak berbeda nyata berdasarkan uji DMRT taraf 5\%.

Gambar 8. Histogram Pemberian EMS terhadap Berat Biji per Buah

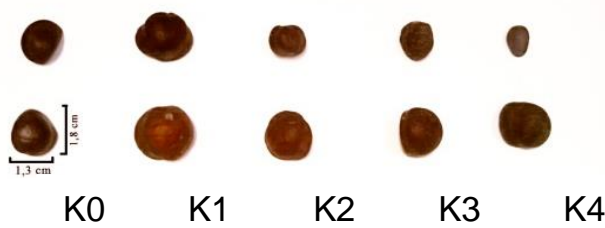

Keterangan :

KO: Konsentrasi EMS $0 \%$

K1: Konsentrasi EMS 0,5\%

K2: Konsentrasi EMS 1\%

K3: Konsentrasi EMS 1,5\%

K4: Konsentrasi EMS $2 \%$

Baris bawah merupakan ukuran biji standar pada setiap perlakuan. Baris atas merupakan ditemukannya penurunan ukuran biji pada beberapa sampel perlakuan.

Gambar 9. Foto Perbandingan Ukuran Biji Salak Pada Setiap Perlakuan

Pemberian EMS pada konsentrasi 1,5\% tidak menunjukkan penurunan berat biji per buah menurut analisis ragam, namun ditemukan 3 biji dengan bentuk yang berbeda dengan biji lain pada umumnya. Biji yang ditemukan pada pemberian EMS dengan konsentrasi $1,5 \%$ ini (gambar 9) memiliki permukaan yang kasar atau mengkerut. Biji ini juga sangat ringan yaitu dengan berat 1,8 gram dan ukurannya kecil dibandingkan dengan biji lain. Tidak hanya pada pemberian EMS dengan konsentrasi 1,5\% yang didapati biji berbeda dengan biji salak pada umumnya. Terdapat penurunan ukuran biji pada perlakuan EMS dengan konsentrasi 1\%, 1,5\%, dan $2 \%$ namun hanya ditemukan beberapa karna sifat mutasi yang acak tidak semua dapat berubah. EMS diduga berpengaruh terhadap peningkatan ploidi sehingga menyebabkan perubahan ukuran biji. Penurunan biji sangat drastis pada penggunaan EMS konsentrasi tinggi pada Jatropha curcas (Selvaraj et al 2010).

Biji paling kecil ditemukan pada konsentrasi EMS 2\% namun memiliki berat yang lebih besar dibandingkan biji yang ditemukan berbeda pada pemberian EMS dengan konsentrasi 1,5\% yaitu sebesar 1,93 gram. Pemberian EMS konsentrasi $0,5 \%$ justru memiliki berat biji paling besar dibanding perlakuan yang lain yaitu dengan berat biji paling tinggi sebesar 5,94 gram. Menurut Nurmayuis et al. (2010) apabila mutagen menghasilkan mutasi pada suatu tanaman dan memungkinkan terjadinya perubahan bahan genetik dan menyebabkan perubahan ekspresi dan diikuti perubahan tingkat metabolism maka perubahan tersebut akan terwariskan, oleh karena itu perlu adanya penelitian lanjutan untuk membuktikannya.

\section{Kadar Gula}

Berdasarkan analisis ragam kadar gula diketahui bahwa pemberian EMS tidak berpengaruh terhadap kadar gula dari buah salak dengan kata lain tidak mempengaruhi rasa dari buah salak tersebut. Kadar gula tertinggi pada pemberian EMS dengan konsentrasi $2 \%$ yaitu sebesar 19,33 brix.Pemberian EMS dengan konsentrasi $1 \%$ memiliki kadar gula paling

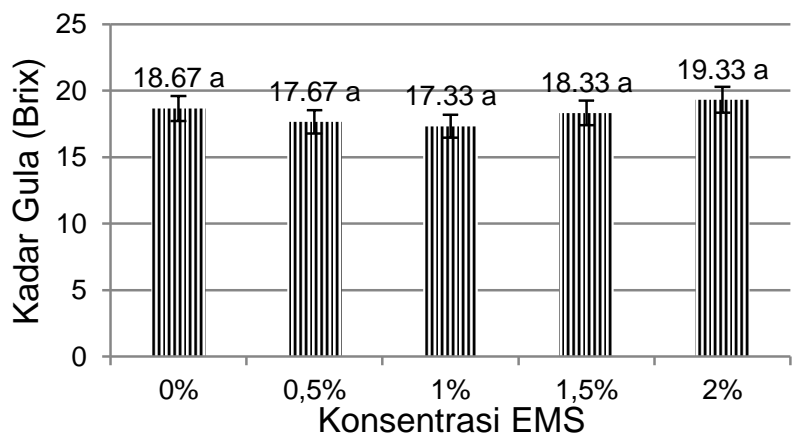

rendah yaitu sebesar 17,33 brix.

Keterangan :

Angka yang diikuti indeks huruf yang sama berarti tidak berbeda nyata

berdasarkan uji DMRT taraf $5 \%$.

Gambar 10. Histogram Pemberian EMS terhadap Kadar Gula Salak

\section{KESIMPULAN}


Kesimpulan yang dapat diperoleh dari penelitian ini adalah:

1. Pemberian EMS pada bunga betina salak sebelum penyerbukan belum dapat menurunkan ukuran biji salak meskipun uji F menyatakan bahwa hasil signifikan, tetapi hasil tersebut berpengaruh nyata terhadap peningkatan ukuran biji.

2. Tidak ada pengaruh pemberian konsentrasi EMS pada bunga betina sebelum penyerbukan terhadap pembentukan buah salak tanpa biji.

\section{Saran}

Sebaiknya dilakukan lebih banyak penelitian tentang perkembangan dan umur bunga salak baik betina maupun jantan sehingga dapat memperkirakan waktu yang tepat untuk pemberian EMS.Penelitihan lanjutan juga perlu dilakukan untuk mengetahui pengaruh EMS terhadap bentuk kromosom.

\section{UCAPAN TERIMAKASIH}

Penelitian ini dilaksanakan di kebun salak milik Bapak dan ibu Yanto di Tapansari, Candibinangun, Pakem, Sleman, Yogyakarta.

\section{DAFTAR PUSTAKA}

Devi, SA., Mullainathan, L. 2012, Effect Of Gamma Rays And Ethyl Methane Sulphonate (EMS) in M3 Generation Of Blackgram (Vigna mungo L. Hepper), African Journal of Biotechnology, 11(15) : 3548-3252.

Gari Ni Made, 2011, Multivariate Analysis Of Bali Salak Cultivars (Salacca zalacca var. Amboinensis(Becc.) Mogea) Based On Leaf Micromorphological Characters, Jurnal Biologi, 15(1) : 15-18.

Jabeen, N., Mirza, M. 2002, Ethyl Methane Sulfonate Enhances Genetic Variability in Capsicum annuum, Asian Journal of Plant Science, 1(4) : 425-428.

Manzila, I., Hidayat, SH., Mariska, I., Sujiprihati, S. 2010, Pengaruh Perlakuan Ethyl Methane Sulfonate pada Tanaman Cabai (Capsicum annuum L.) dan Ketahanannya terhadap Chilli Veinal Mottle Virus (ChiVMV), J Agron Indonesia, 38(3) : 205211.

Nandariyah, Utami, TD., Purwanti, T. 2014, Rekayasa Peningkatan Mutu Buah Salak melalui Penggunaan ZPT GA $\mathrm{G}_{3}+\mathrm{BA}$ dan Ethyl Methane Sulfonat, Prosiding Seminar Nasional Fakultas Pertanian, UNS Surakarta.

Nurmayulis, Susiyanti, Kartina, AM., Syabana, MA. 2010, Peningkatan Keragaman Tanaman Garut Dengan Pemberian
Berbagai Konsentrasi Dan Lama Perendaman Ethyl Methan Sulphonat, J Agrivigor, 10(1) : 1-9.

Nurrochman, Trisnowati, S., Muhartini, S. 2013, Pengaruh Pupuk Kalium Klorida dan Umur Penjarangan Buah terhadap Hasil dan Mutu Salak (Salacca zalacca Gaertner Voss) 'Pondoh Super', Journal Online UGM, http:/journal.ugm.ac.id/jpti/pdf. Diakses pada 15 Maret 2016.

Pratiwi, Made, P., Ida, AA. 2013, Pengaruh Ethyl Methane Sulphonate (EMS) Terhadap Pertumbuhan dan Variasi Tanaman Marigold (Tagetes sp.), Jurnal Agrotrop, 3(1) : 23-28.

Qosim, WA., Yuwarlah, Y., Hamdani, JS., Rachmadi, M., Perdani, SM. 2015, Pengaruh Mutagen Etil Metan Sulfonat Terhadap Regenerasi Tunas pada Dua Genotip Manggis Asal Purwakarta dan Pandeglang, J Hort, 25(1) : 9-14.

Saba, N., Mirza, B. 2002, Ethyl Methane Sulfonate Induced Genetic Variability in Lycopersicon esculentum, Int J Agri Biol, 4(1) : 89-92.

Selvaraj, R., Dhakshanamoorthy, D., Chidambaram, A. 2010, Physical And Chemical Mutagenesis In Jatropha curcas L. To Induce Variability In Seed Germination, Growth And Yield Traits, Journal of Biology, 55(2) : 113-125.

Wiguna, G., Prasodjo, R., Sumpena, U. 2011, Efektivitas Ethyl Methane Sulfonate (EMS) terhadap Pembentukan Tanaman Wortel (Daucus carota L.) Mandul Jantan, Jurnal Ilmu-ilmu Pertanian, 7(2) : 25-32. 